\title{
Do Pequeno ao Grande Líbano: os desafios contemporâneos da República Libonesa
}

From Small to Greater Lebanon: the contemporary challenges of the Lebanese Republic

Del Pequeño al Gran Libano: los desafios contemporáneos de la República Libanesa

Danny Zahreddine ${ }^{1}$

DOI: $10.5752 /$ P.1809-6182.2020v17n2p29

Recebido em: 15 de julho de 2020 Aceito em: 27 de agosto de 2020

\begin{abstract}
Resumo
Marcado por uma história de múltiplos conflitos internos, e de intervençôes externas, a República Libanesa é o resultado de decisóes pretéritas que foram fundamentais na determinação dos seus dilemas atuais. Este artigo apresenta uma análise histórica da criação do Líbano, desde a formação do Emirado do Monte Líbano, passando pelo mandato francês, até a criação do "Grande Líbano", bem como uma reflexão sobre seus dilemas contemporâneos.

Palavras-chave: Líbano. Minorias Religiosas. Guerra Civil.
\end{abstract}

\begin{abstract}
Marked by a history of multiple internal conflicts and external interventions, the Lebanese Republic is the result of past decisions that were fundamental in determining its current dilemmas. This article presents a historical analysis of the creation of Lebanon, from the formation of the Emirate of Mount Lebanon, through the French mandate, until the creation of "Greater Lebanon", as well as a reflection on its contemporary dilemmas.

Keywords: Lebanon. Religious Minorities. Civil war.

\section{Resumen}

Marcada por una historia de múltiples conflictos internos e intervenciones externas, la República Libanesa es el resultado de decisiones pasadas que fueron fundamentales para determinar sus dilemas actuales. Este artículo presenta un análisis histórico de la creación del Libano, desde la formación del Emirato del Monte Libano, pasando por el mandato francés, hasta la creación del "Gran Libano", asi como una reflexión sobre sus dilemas contemporáneos.

Palabras clave: Líbano. Minorías religiosas. Guerra civil.
\end{abstract}

\footnotetext{
1 Doutor em Geografia pelo Programa de Pós Graduação em Tratamento da Informação Espacial (PUC Minas). Professor do Departamento de Relaçôes Internacionais da PUC Minas. Membro permanente do Programa de Pós Graduação em Relaçôes Internacionais (PUC Minas). Líder do Grupo de Estudo Oriente Médio e Magreb - CNPq (GEOMM). ORCID: https://orcid. org/0000-0001-7400-0300
} 


\section{Introdução}

Os protestos que se desencadearam no Líbano a partir de outubro de 2019, e a grande explosão ocorrida no Porto de Beirute em 04 de agosto de 2020 são reveladores das tensóes que envolvem a sociedade libanesa e seu sistema político. Essas manifestaçôes que adentraram o ano de 2020 são resultado de uma série de questôes. Os ecos do passado ainda refletem diretamente nos dilemas contemporâneos dos libaneses, e se manifestam na tomada de decisão dos atores políticos do regime sectário em vigor, nos desafios da política internacional e nas crises econômicas que assolam o país, no transcurso desses quase 80 anos da Proclamação da República Libanesa.

O dia $1^{\circ}$ de setembro de 1920 foi uma data marcante para a história do Líbano e para seu futuro. A criação do "Grande Líbano", por decreto do então General francês Henri Gouraud, afetaria profundamente as relações político-sociais dos grupos confessionais pertencentes a esta nova entidade nacional. Neste sentido, entender o processo histórico que levou à criação da República Libanesa e os desafios de sua sociedade multiconfessional é de fundamental importância para a compreensão de seus dramas atuais e de suas possibilidades futuras.

Oficialmente, o governo libanês reconhece 18 comunidades religiosas ${ }^{2}$, que participam da vida política do país. Esta realidade é reveladora da complexidade que é lidar com a cena política do Estado. Entre os libaneses existem percep-

2 Os grupos confessionais libaneses são: Alauitas, Armênios Católicos, Armênios Ortodoxos, Assírios, Caldeus Católicos, Católicos Romanos, Coptas, Drusos, Gregos Católicos Melquitas, Gregos Ortodoxos de Antioquia, Ismaelitas, Judeus, Maronitas, Protestantes, Siríacos Católicos, Siríacos Ortodoxos, Sunitas, Xiitas. çóes muito particulares acerca da origem do Estado e da identidade nacional de seus cidadáos.

Com frequência vemos nas comunidades diaspóricas libanesas, grupos defendendo o legado fenício como a principal fonte identitária. Para outros, a identidade árabe é a principal referência nacional. Tais percepçôes são defendidas por grupos religiosos distintos, gerando uma perspectiva muito particular de unidade nacional (KAUFMAN, 2004). Desta forma, buscarei indicar neste artigo os elementos que levaram à criação do Líbano contemporâneo, e os fatores que tornam a solução dos problemas atuais um grande desafio para a sociedade libanesa.

\section{O Emirado do Monte Líbano}

A criação do Emirado do Monte Líbano no Império Otomano pelos emires drusos da dinastia Maan, pode ser considerada um dos fatores primordiais para o desenvolvimento da futura nação libanesa. Neste sentido, a forma como o Império controlava suas possessóes territoriais e as minorias religiosas, permitiram a organização de forças políticas e sociais locais, o que contribui para o processo de formação do futuro Líbano.

O atual território libanês é constituído basicamente por duas cadeias montanhosas que se estendem de norte a sul, com um fértil vale ao centro e o mediterrâneo banhando a sua costa. A regiáo do Emirado do Monte Líbano era formada pela área compreendida entre o litoral mediterrâneo até o cume da primeira cadeia montanhosa em direção a leste, o Monte Líbano, tendo como limite norte o Sanjak $k^{3}$ de

\footnotetext{
3 Sanjak era uma divisão administrativa do Império Otomano que pode ser definido como um distrito de um Vilayet.
} 
Trípoli (que não compunha o Emirado), e o limite sul o Sanjak de Sidon (que também não compunha o Emirado). O Sanjak de Beirute era a sede do Vilayet ${ }^{4}$ de Beirute, que controlava os Sanjaks de Latakia, Tripoli, Akkar e Nablus.

De acordo com Traboulsi (2012), a criação do Emirado do Monte Líbano, como uma região autônoma dentro do Império Otomano, em 1523, teve impacto fundamental para o início da consolidação da futura nação libanesa por alguns fatores: o primeiro deles diz respeito à integração de todo Monte Líbano, a partir de uma autoridade local constituída, expandindo em alguns momentos tais possessóes até à Síria e à Palestina histórica; a segunda se relaciona à presença considerável de cristãos na região; a terceira aponta para o precoce desenvolvimento da atividade produtiva naquela área, com a implementação da produção e comercialização da seda, pelos príncipes drusos e cristáos maronitas; e o quarto fator diz respeito ao longo relacionamento do emirado com a dimensão internacional e as experiências de intervençôes externas sofridas a partir das potências europeias.

Todas essas características, consolidadas em um período que abrange o ano 1523 a 1842, foi um primeiro momento de formação daquilo que seria conhecido como o pequeno Líbano. O Emirado do Monte Líbano era uma unidade semiautônoma, pertencente ao Império Otomano, que era administrada por emires locais reconhecidos e aceitos pelo Império. A manutenção desta elite local estava ligada ao controle das terras e à arrecadação de tributos pela utilização e produção destas propriedades. Existiam obrigaçôes que estes emires locais deveriam cumprir junto ao Império Otomano,

\footnotetext{
4 Vilayet era uma divisão administrativa do Império Otomano que pode ser definido como província ou departamento. Um Vilayet era composto por vários Sanjaks.
}

dentre elas a coleta e envio de impostos ( $\operatorname{tax}$ farms), e o controle da região frente aos inimigos do Império (TRABOULSI, 2012).

O Emirado do Monte Líbano era ocupado majoritariamente por cristãos maronitas e drusos, além de outras minorias cristãs e muçulmanas. Até o ano de 1841 o Emirado foi governado por emires drusos, muçulmanos sunitas, e por uma ocasião, por um Emir de descendência sunita mas convertido ao cristianismo maronita. Porém, dois foram os Emires que mais influenciaram a criação do Líbano moderno, o Príncipe Fakhreddine II da dinastia Maan (1572-1635), e o Emir Bashir Shihab II (1767-1850).

Fakhreddine II foi responsável pela maior integração do Monte Líbano, pois além de seu forte controle sob a região, estimulou o desenvolvimento da produção de seda e a participação das comunidades maronitas nesta atividade. Além disto, Fakhreddine II também incentivou o deslocamento de cristáos maronitas para outras regióes do Monte Líbano, principalmente áreas próximas do vale do Békaa e do Shouf, porção sul do território, ocupado majoritariamente por drusos, para o desenvolvimento da atividade com a seda (SALIBI, 1988, p. 67).

O emir druso conseguiu ocupar uma grande porção do território que ia além do próprio Monte Líbano, como o vale do Békaa, a cidade de Palmira (atual Síria), áreas da atual Jordânia e Palestina, o que gerou desconfiança no sultão otomano. Fakhreddine II também foi responsável pela tentativa de tornar independente o emirado, com o apoio dos Maronitas, Vaticano e dos Médicis de Florença.

Quando os planos para independência foram descobertos pelos otomanos, exilou-se por cinco anos em Florença. De volta ao Monte Líbano buscou retomar o controle da região. 
Ao final, sem o apoio da comunidade drusa, acabou sendo capturado pelo exército otomano e levado a Constantinopla, onde foi executado dois anos após sua prisão, em abril de 1635 (TRABOULSI, 2012).

Já Bashir Shihab II foi o mais longevo dos emires no poder no Monte Líbano, de 1788 a 1840. Bashir pertencia a uma família sunita, que parte se converteu ao cristianismo maronita. Ele foi responsável pelo recrudescimento das relaçóes sectárias entre maronitas e drusos, favorecendo os maronitas em alguns momentos, reduzindo a influência política e econômica dos drusos, e levando a embates sectários cada vez mais constantes entre estes dois grupos religiosos. Com o fim da presença egípcia na regiāo, e a retomada do controle Otomano, o Emir foi exilado com sua família em Malta. Muitas características do sectarismo religioso do Líbano moderno advêm das políticas adotadas por Bashir Shihab II (TRABOULSI, 2012).

Em 1841, os confrontos sectários entre drusos e maronitas aumentaram consideravelmente, em função do sistema otomano de controle da terra, que se assemelhava a um sistema feudal, não-sectário, em que os senhores locais eram responsáveis pela coleta de impostos, pelo uso da terra e pelo controle da ordem local. Este sistema era conhecido como Iqta’a, e os responsáveis pela sua realização o Muqata ji (KHALAF, 2002).

Boa parte das terras estava sob o controle dos drusos, enquanto os maronitas, camponeses e comerciantes em sua maioria, estavam submetidos a este sistema feudal em áreas de maioria cristấ ${ }^{5}$. Os agricultores maronitas ini-

\footnotetext{
5 É importante ressaltar que também existiam Muqata ¡jis maronitas, principalmente na regiâo de Keserwan, onde praticavam a mesma função que os emires drusos. A concentração maior de emires drusos se dava na região ao sul do Monte Líbano (Jabal Shouf).
}

ciaram greves e ataques contra os responsáveis pelas terras nesse período, em sua maioria drusos. É importante salientar que nesse momento, a população cristã Maronita do Emirado do Monte Líbano era bem superior à população drusa (HARRIS, 2012).

Em 1843 o Império Otomano decidiu dividir o Emirado em duas províncias (Qaymaqam duplo), ao norte, administrada pelos maronitas, e ao sul, administrada pelos drusos, separadas pela antiga estrada que ligava Beirute a Damasco. Isto representou o fim do Emirado do Monte Líbano. A decisão otomana foi resultado da intensa pressão da Áustria, Reino Unido e França. Porém, a ação tornou a relação entre drusos e maronitas ainda mais tensa, pois exacerbou o sentimento sectário entre estas duas comunidades. Terras drusas que estavam localizadas na porção norte, sofriam ataques de agricultores maronitas, e cidades de maioria cristâ, na porção sul do Monte Líbano (administrada pelos drusos) não aceitavam a autoridade drusa. A divisão do Monte Líbano aprofundou o sentimento identitário das comunidades confessionais, gerando um ciclo de violência constante, com açóes de ambos os lados (TRABOULSI, 2012).

O ápice desta tensão se deu no ano de 1860, quando após uma série de revoltas maronitas contra propriedades drusas, gerou uma resposta drusa que levou à morte de milhares de maronitas, principalmente nas cidades de Zahle, Deir al Qamar e Damasco. (TRABOULSI, 2012). Um aspecto importante para entender a intensificação dos embates é a própria influência que França e Reino Unido tiveram nas comunidades maronita e drusa respectivamente. Os franceses, apoiando os maronitas, enviavam dinheiro e armas, além de estimular o embate contra os drusos. Os ingleses, intercediam pelos 
Muqata ji drusos frente ao Império Otomano, para a manutençấo de sua autoridade local e terras (HARRIS, 2012). O embate internacional entre França e Reino Unido também se refletia no Monte Líbano.

O impacto da morte de milhares de cristãos maronitas levou os franceses a pressionarem os Otomanos a criarem uma província autônoma no Monte Líbano. Esta província teria o objetivo de resguardar as vidas e o legado do cristianismo no Oriente Médio, além dos interesses geopolíticos e econômicos da própria França. Vale lembrar que o Império Otomano já utilizava o sistema de Millet antes das reformas Tanzimat, que conferia às minorias confessionais relativa autonomia. Além disso, o império já se encontrava em franca decadência, o que facilitou o pleito francês e a intervenção europeia. Esse momento também representou o início da falência do sistema semifeudal Otomano, representado pelo sistema Iqta’a e os Muqata jis, e o início da ascensão política e econômica dos maronitas, em detrimento dos drusos.

\section{Figura 1 - O Qaymaqarm Duplo do Monte Líbano}

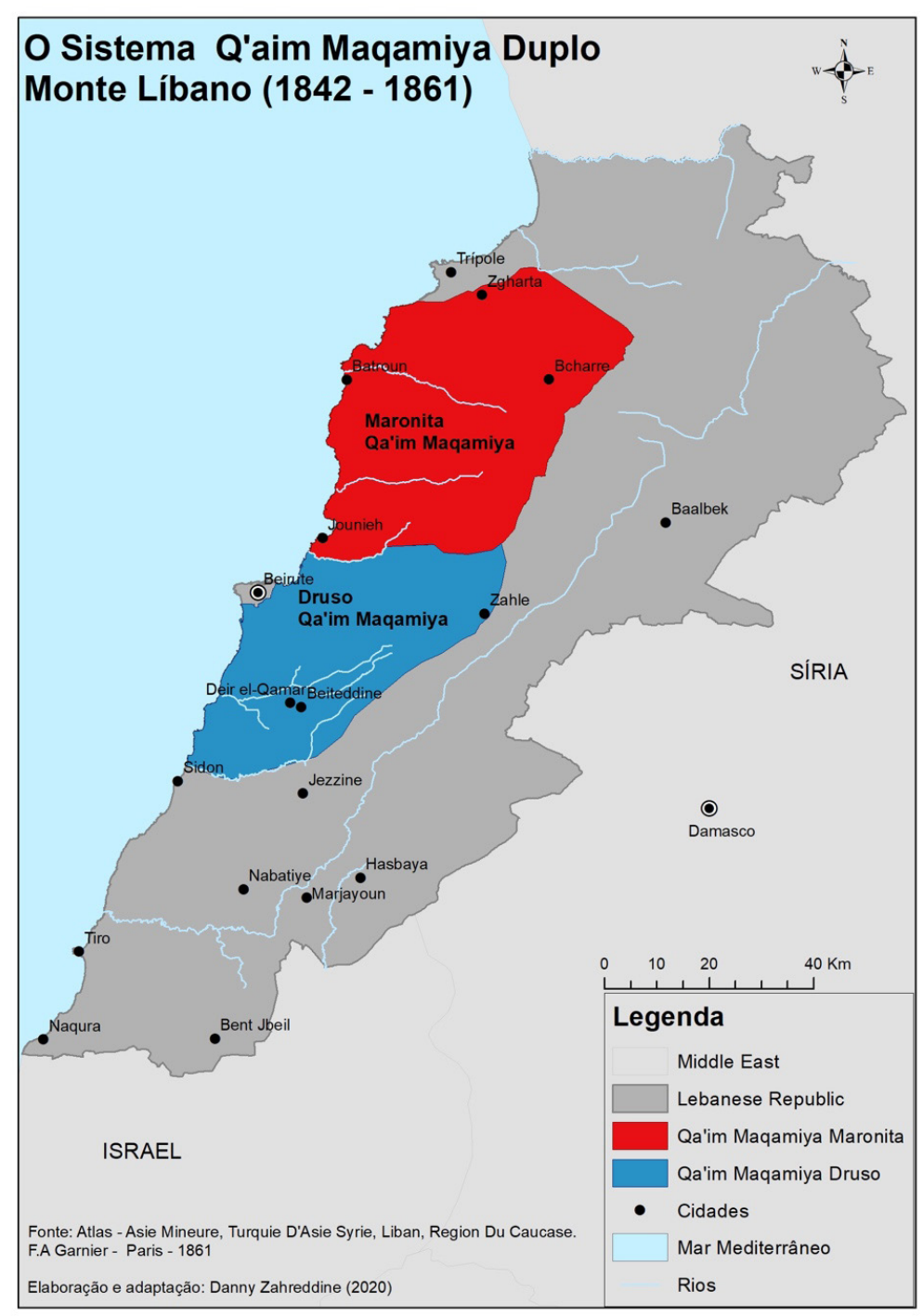

Fonte: Elaborado e adaptado pelo autor com dados de (GARNIER, 1861). 


\section{Do Pequeno Líbano à República Libanesa}

Em 9 de junho de 1861 o Império Otomano criou a província semiautônoma do Monte Líbano. O Mutassarifat do Monte Líbano foi governado por vários cristãos não libaneses, sob a supervisão da França, Reino Unido, Áustria, Prússia e Rússia (TRABOULSI, 2012). Este sistema funcionou até 1915, e quando os Otomanos perderam a Primeira Guerra Mundial, franceses e ingleses ocuparam a região, sob os auspícios dos Acordos secretos de Sykes Picot.

Os desdobramentos do fim da Primeira Guerra Mundial foram sentidos fortemente no Oriente Médio. As promessas feitas ao Xerife de Meca, Hussein Ibn Ali, pelos britânicos, de criação de um Reino Árabe, de acordo com as Cartas Hussein-Mcmahon (KAMRAVA, 2005), juntamente com as aspiraçôes francesas e das elites locais (cristãos libaneses e muçulmanos árabes), gerou uma disputa acirrada entre estes grupos.

Faissal, filho de Hussein, que havia chegado em Damasco, bem como os muçulmanos que viviam no vale do Békaa e na porção sul do Líbano, defendiam a manutenção de uma Grande Síria, ligada ao mundo árabe. Os cristãos Ortodoxos que também moravam nesta área apoiavam o pleito árabe, e eram contra a anexação de tais terras para a criação de um Grande Líbano. Por outro lado, o Patriarca Maronita Elias Huwayik e boa parte dos cristãos libaneses (principalmente os maronitas), e os próprios franceses, almejavam a criação de um Grande Líbano (TRABOULSI, 2012).

A ideia de um Grande Líbano nascia da vontade da França e dos Maronitas de criar uma entidade política cristã no Oriente Médio que fosse viável. Neste sentido, o "Pequeno Líbano" seria extremamente dependente economicamente das naçôes vizinhas, se mantivesse somente a região do Monte Líbano. Desta forma, a pressão exercida pelo Patriarca Maronita Elias Huwayik sobre as autoridades francesas surtiu o efeito esperado quando da saída do Primeiro Ministro francês Georges Clemenceau.

Esta nova Unidade Política agregaria ao Monte Líbano as cidades de Sidon e a região sul até a fronteira com a Palestina; Trípole e o antigo Sanjak de Akkar, e todo o Vale do Békaa até o cume do Antilíbano. Após o avanço das forças francesas em Damasco, e a retirada de Faissal da regiáo, o General Gouraud finalmente oficializa a criação do Grande Líbano em 1 de setembro de 1920.

Este momento é crucial para os desafios do Líbano contemporâneo, pois até 1920, 80\% da população do Monte Líbano era cristã, e o restante formado por drusos e outras minorias muçulmanas (HARRIS, 2012). O "Pequeno Líbano" englobava aproximadamente o que foi o Emirado do Monte Líbano. Neste território, com aproximadamente $4.000 \mathrm{~km}^{2}$, a predominância era dos cristãos maronitas.

A decisão de alargar as fronteiras do "Pequeno Líbano" buscava viabilizar economicamente uma nova entidade nacional, pois o Monte Líbano já havia experimentado situaçóes de fome extrema ao final do século XIX e durante a Primeira Guerra Mundial. A existência de limitada terra agricultável, da decadência da indústria da seda e a própria conjuntura da guerra, foram os fatores principais que levaram à fome. A integração do Vale do Békaa e das grandes cidades litorâneas visava minorar esta fragilidade. Porém, ao agregarem tais áreas, os Cristãos Maronitas que compunham $58 \%$ do total da população do Monte Líbano diminuíram sua representatividade demográfica para 33\% (HARRIS, 2012), não sendo mais o grupo confessional majoritário, em função dos milhares de muçulmanos que habitavam as novas regiôes anexadas. A busca pela viabilidade econômica criou um profundo dilema político e social. 


\section{Figura 2 - Pequeno e Gronde Líbano}

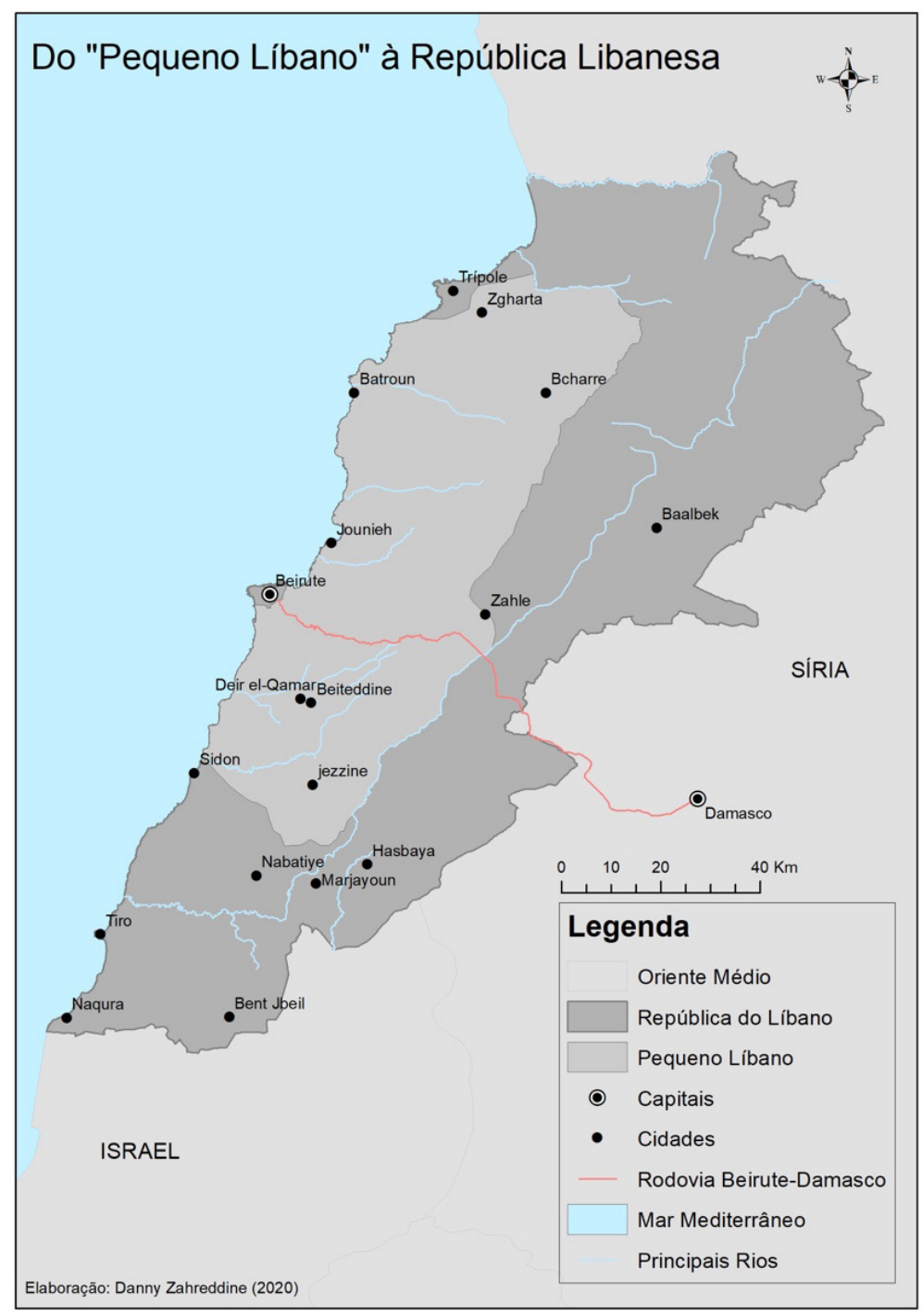

Fonte: Elaborado e adpatado pelo autor com dados de (SALIBI, 1988)

Neste sentido, o decreto do General Gouroud criou um Líbano cristão extremamente dependente do mandato francês, pois seu apoio aos Maronitas deveria ser mais contundente em função de duas razões principais: das populaçóes muçulmanas que não queriam fazer parte desta nova unidade política e pela diminuição da proporção entre cristãos e muçulmanos. De um lado temos cristãos maronitas que visam criar no Líbano a sua pátria, ligada à Europa, por outro lado, muçulmanos sunitas e xiitas que querem se manter ligados à "Grande
Síria”. É deste cenário que as divisôes da sociedade libanesa vão se aprofundar, pois além do sectarismo religioso herdado do século XIX, a absorção de outras comunidades confessionais em número expressivo tornará mais difícil o pacto social e político deste novo país.

$\mathrm{Na}$ tentativa de criar uma solução para a questão política e identitária libanesa, uma constituição é elaborada em 1926. Essencialmente liberal e de espírito democrático, a constituição indicava a divisão igualitária de espaço político para cristãos e muçulmanos; aponta 
que o sistema confessional deve ser temporário e transitório, e que o Líbano seria um país pertencente ao mundo árabe. Porém, a constituição libanesa não indicou como seria a distribuição de cargos e funçôes entre as religiôes, algo que será resolvido com o Pacto Nacional em 1943. É importante salientar que a constituição libanesa é criada sob o mandato francês, sendo o Líbano ainda subordinado àquele país.

Em 1932 a França, juntamente com as autoridades libanesas, elabora um censo demográfico para auxiliar na construção da cidadania libanesa, haja vista o fim do Império Otomano. Além disto, o censo seria importante pois serviria de base para o estabelecimento da representação política do país e a divisão do poder entre as comunidades confessionais, no governo, parlamento e no serviço público.

Para Maktabi (1999) os resultados do Censo de 1932 revelaram uma metodologia enviesada, que buscava favorecer um Líbano majoritariamente cristão. A aceitação da inclusão de emigrantes no censo foi legitimada por Lei em 19 de dezembro de 1931, emitida menos de um mês antes do anúncio da reali- zação do censo, pelo Decreto 8837 em 15 de janeiro de 1932. A lei estipulava que deveria se considerar os emigrantes que haviam deixado o país a partir de 30 de agosto de 1924 . A questão é que milhares de cristãos foram aceitos, mesmo tendo emigrado antes de 30 de agosto de 1924.

Outro ponto interessante levantado por Maktabi (1999) é sobre os estrangeiros no censo de 1932. Observa-se em documentos da época a disposição das autoridades francesas e libanesas em garantir para os cristãos armênios e de outras nacionalidades, que entraram no país como refugiados, o direito à cidadania libanesa, em função da relação com o cristianismo. No entanto, populaçóes curdas, que também se refugiaram no Líbano, mas de origem muçulmana, não receberam o mesmo tratamento, sendo considerados estrangeiros. Este e vários exemplos revelam o esforço que França e as autoridades libanesas sob o mandato francês, empreenderam para garantir um sistema político com maioria cristã. Estas informaçóes podem ser observadas claramente na tabela 1 , sobre o resultado do Censo de 1932.

Tabela 1 - Residentes e Emigrantes Liboneses por Grupo Religioso de Acordo com o Censo de 1932

\begin{tabular}{|c|c|c|c|c|c|c|}
\hline & $\begin{array}{c}\text { Resident } \\
\text { citizens }\end{array}$ & $\begin{array}{l}\text { Residents in } \\
\% \text { of } \\
\text { total resident } \\
\text { citizens }\end{array}$ & Emigrants & $\begin{array}{l}\text { Sect in \% of } \\
\text { total emigrant } \\
\text { citizenry }\end{array}$ & $\begin{array}{c}\text { Total citizens } \\
\text { (emigrants } \\
\text { residents) }\end{array}$ & $\begin{array}{l}\text { Sect in \% of } \\
\text { total Lebanese } \\
\text { citizenry }\end{array}$ \\
\hline Maronites & 227,800 & 28.7 & 123,397 & 48.4 & 351,197 & 33.5 \\
\hline Greek Orthodox & 77,312 & 9.7 & 57,031 & 22.4 & 134,343 & 12.8 \\
\hline Greek Catholic & 46,709 & 5.9 & 29,627 & 11.6 & 76,336 & 7.3 \\
\hline Total Christians & 396,946 & 50.0 & 215,844 & 84.7 & 612,790 & 58.5 \\
\hline Sunnis & 178,100 & 22.5 & 17,205 & 6.7 & 195,305 & 18.6 \\
\hline Shiis & 155,035 & 19.5 & 11,501 & 4.5 & 166,536 & 15.9 \\
\hline Druze & 53,334 & 6.7 & 8,750 & 3.4 & 62,084 & 5.9 \\
\hline Other non-Christians & 9,981 & 1.3 & 1,678 & 0.7 & 11,659 & 1.1 \\
\hline Total non-Christians & 396,450 & 50.0 & 39,143 & 15.4 & 435,593 & 41.5 \\
\hline Total & 793,396 & 100 & 254,987 & 100 & $1,048,383$ & 100 \\
\hline
\end{tabular}


O controle restritivo da concessão de cidadania libanesa foi uma política comum adotada pelo governo até a guerra civil de 1975 . Dentre as razóes para tais políticas, e para ausência de outro censo demográfico, estava o interesse de manter a ideia de que o Líbano se mantinha majoritariamente cristão, em uma realidade que já estava em franca transformação (MAKTABI, 1999). Por esta razão a questão demográfica é táo sensível até os dias de hoje, pois será sobre ela que todo o sistema político libanês se sustentará.

Para acomodar os interesses da população cristã e da população muçulmana, em 1943 políticos representantes destes dois grupos religiosos aceitam a criação de um acordo não-escrito, conhecido como Pacto Nacional. O Pacto Nacional representou a divisão do poder político nas principais esferas decisórias e de poder: governo, parlamento e serviço público. Tendo como base o resultado do Censo de 1932, o Pacto Nacional estabeleceu que o presidente do Líbano seria um cristão maronita, o Primeiro Ministro um muçulmano sunita, o presidente do parlamento um muçulmano xiita, e as cadeiras do parlamento seriam divididas em uma proporção de 6 cristãos para 5 muçulmanos, isto significava 54 cadeiras para cristãos (Maronitas, Gregos Ortodoxos e Gregos Católicos) e 45 para muçulmanos (sunitas, xiitas e drusos). Essa proporção se repetiria em todas as esferas decisórias. Este é o sistema confessional libanês fundado em 1943. Como aponta Zisser (2000), a forma final do Pacto Nacional foi dada em uma reunião do futuro presidente do Líbano, o cristão Maronita Bechara el Khoury, juntamente com seu futuro Primeiro Ministro, o sunita Riad al-Solh, no dia 19 de setembro de 1943.

Para Calfat (2018), o sistema político libanês pode ser definido como uma forma de democracia consociativa, própria de socieda- des que são marcadas por forte componente de pluralidade étnico-religiosa e fragmentação política. O conceito de regimes ou instituiçóes consociais foi apresentado pelo cientista político holandês Arendt Lijphart. Para o autor, "Democracia consocial significa um governo formado por um cartel de elites projetado para transformar uma democracia com uma cultura política fragmentada em uma democracia estável” (LIJPHART, 2008, p. 31, tradução nossa) ${ }^{6}$.

Sistemas políticos consociativos buscam evitar o conflito a partir da distribuiçáo da representatividade minoritária de tais grupos no executivo e no parlamento, e geralmente são representados por suas elites. A despeito de estar inserido em uma região geopoliticamente instável, de 1943 a 1975, o país manteve-se relativamente estável, com alguns momentos de crise mais aprofundada, como nos anos de 1958 e 1968. Boa parte das crises estavam ligadas à Guerra Fria, ao conflito palestino-israelense e a polarização dos partidos políticos libaneses de acordo com suas comunidades religiosas.

\section{Da Independência à Guerra Civil de 1975}

Em 21 de setembro de 1943 Bechara el Khoury foi eleito o primeiro presidente do Líbano independente, e escolheu Riad al-Solh como seu Primeiro Ministro. A eleição de Khoury representou um duro golpe para os franceses, pois seu posicionamento era de acabar com o mandato francês e implementar o Pacto Nacional, com o intuito de apaziguar os medos de cristãos e muçulmanos e viabilizar o novo Estado. O Pacto Nacional sinalizou para

\footnotetext{
6 Consociational democracy means government by elite cartel designed to turn a democracy with a fragmented political culture into a stable democracy.
} 
os cristãos do Líbano que seu país se manteria independente, e não seria absorvido por nenhuma nação árabe. Ao mesmo tempo, para os muçulmanos, o Pacto nacional significaria a preservação da identidade árabe do Líbano e o afastamento da interferência francesa no país.

O mês de novembro de 1943 foi simbólico para a história libanesa, pois representou a última tentativa do governo em acabar com o mandato francês. No dia 8 de novembro de 1943 uma proposta de emenda constitucional é apresentada à Câmara libanesa. O movimento, feito pelo novo governo (Khoury e Solh), sugeria a remoção de qualquer mençáo ao papel da França como força mandatária do Líbano da constituição. A proposta foi aprovada e criou uma profunda crise com o governo francês (De Gaulle), que em 11 de novembro de 1943 prendeu praticamente todo o governo recém-eleito no forte de Rashaya (ROGAN, 2009). Após intensos protestos no Líbano, e forte pressão internacional, especialmente dos britânicos, no dia 22 de novembro de 1943, Khouri, Solh e o restante dos detidos são liberados. Em função deste fato que se comemora no dia 22 de novembro o dia da independência libanesa. Nasce desta forma a República do Líbano.

Nos anos seguintes os desafios foram grandes, e vários momentos colocaram em dúvida a governabilidade do país. As variáveis externas e a sensibilidade às questóes demográficas, aos poucos começaram a erodir a estabilidade política e social. A Primeira Guerra Árabe Israelense de 1948; o grande fluxo de refugiados palestinos e os posteriores embates entre a Organização para Libertação da Palestina (OLP) e Israel, em território libanês, acarretarão cada vez mais impactos para o cenário doméstico. Além disso, as guerras civis de 1958 e 1975 revelarão as dificuldades de se manter o Pacto
Nacional diante dos desafios da Política Internacional e dos antagonismos presentes entre cristãos e muçulmanos no Líbano.

O período de 1952 a 1958 foi especialmente turbulento. A eleição do presidente $\mathrm{Ca}$ mille Chamoun, juntamente com uma série de outras variáveis externas e domésticas, criou uma combinação que levaria o país a uma breve guerra civil. Podemos citar como principais razóes para a crise de 1958 os seguintes pontos: o perfil centralizador e mais autoritário do presidente; o ambiente de polarização política que ocorria no Oriente Médio, em razão da ascensão do Pan-Arabismo e da liderança do presidente egípcio Gamal Abdel Nasser; a Guerra Fria e a preocupação do presidente estadunidense Eisenhower com a expansáo do comunismo pelo Oriente Médio; e a aproximação do governo libanês com os Estados Unidos (EUA). Todos estes fatores combinados geraram um ambiente de extrema instabilidade interna.

A relação com os países árabes começou a se deteriorar quando Chamoun se recusou a cortar relaçóes com Reino Unido e França, a pedido das naçóes árabes e islâmicas, em razão da Guerra do Canal de Suez em 1956. A postura do presidente libanês, de falta de solidariedade com o governo egípcio, colocou em rota de colisão os partidos muçulmanos (incluindo drusos), em sua maioria de orientação Pan-arabista, com os partidos cristãos, em sua maioria de direita e pró-ocidente.

A oposição era representada pelos seguintes partidos: Partido Socialista Progressita, Partido Comunista Libanês e Al Mourabitoun, entre outros. Rashid Karami, Kamal Jumblatt e Saeb Salam foram as principais lideranças de oposição. Já os partidos de apoio ao governo eram formados pelo próprio partido do presidente, o Partido Nacional Liberal, as Falanges 
Libanesas (Kataeb), e outras forças políticas cristâs. O presidente Camille Chamoun, assim como Pierre Gemayel e Naim Moghabghab, além do próprio Exército Libanês, representavam a base de apoio do governo.

A constante aproximação de Camille Chamoun ao bloco de apoio estadunidense na regiáo, representado pelo Pacto de Bagdá7, e a adoção da Doutrina Eisenhower a partir de março de 1957, gerou forte insatisfação no bloco muçulmano pró-árabe. A partir de manobras na legislação eleitoral, o governo conseguiu reduzir os assentos da oposição nas eleiçóes parlamentares subsequentes, gerando cada vez mais protestos. Com a marginalização dos muçulmanos da política, e da feroz repressão contra eles nas ruas, as açôes de Chamoun começaram a dividir os próprios partidos cristáos, agora preocupados com uma provável guerra civil entre muçulmanos e cristão libaneses (TRABOULSI, 2012).

A crise se agravou em março de 1958, quando o presidente Camille Chamoun sinalizou que poderia tentar estender seu mandato, o que levou a uma resposta imediata dos principais partidos de oposição, principalmente daqueles ligados ao nacionalismo árabe e de inspiração socialista. Com a criação da República Árabe Unida, várias personalidades do bloco de oposição libanesa sinalizavam que o país deveria se unir ao Egito e à Síria. Uma frente de oposição foi criada com representantes muçulmanos, drusos e de alguns partidos cristãos. Os embates se tornaram violentos, e depois de dois meses de confrontos, a oposição controlava

\footnotetext{
7 A Organização do Tratado Central (CENTO), mais conhecida como Pacto de Bagdá, foi uma aliança militar criada em 1955, estimulado pelo governo estadunidense do presidente Eisenhower e formado por Reino Unido, Turquia, Iraque, Paquistão e Irã. O objetivo da Aliança era a manutenção de auxílio mútuo entre os países em caso de agressão externa e a contenção do avanço do bloco Soviético na região.
}

mais de três quartos do país. Quando da eminência das forças muçulmanas e drusas de controlarem o Aeroporto Internacional de Beirute e o porto da cidade, o presidente libanês pediu ajuda militar aos Estados Unidos, para assegurar o fim dos confrontos e a manutenção de seu mandato. Esta operaçáa ficou conhecida como Operação Blue Bat (TRABOULSI, 2012).

A guerra civil de 1958 revelou como o Líbano estava exposto às disputas da Guerra Fria, e como as visôes muitas vezes antagônicas de suas lideranças, que vacilavam entre uma postura neutralista ou de reafirmação de apoio a certos atores regionais, trazia grande instabilidade para o país. Além disto, a queda de regimes favoráveis aos Estados Unidos, como no Iraque, aumentou a preocupação dos EUA com o avanço Soviético no Oriente Médio. Com a intervenção militar estadunidense em 15 de julho de 1958, as partes contenciosas entraram em acordo, o que garantiu o término do mandato do presidente Camille Chamoun, e a criação de um governo de coalizão, sob a presidência do general cristão Fuad Shihab.

Os anos seguintes foram de busca por governabilidade e enfrentamento das desigualdades políticas e sociais que afetavam o Líbano como um todo. Porém, a experiência da crise de 1958 não foi suficiente para impedir uma outra guerra civil ainda mais violenta. As razóes que levaram à eclosão da Guerra Civil de 1975 foram várias, mas a questão palestina e a presença da OLP no país, tornava as relaçóes entre muçulmanos e drusos com os cristãos maronitas ainda mais tensa. Além disto, a transformação do quadro demográfico libanês, a participação ativa de Síria e Israel no conflito, bem como a polarização da Guerra Fria, intensificou os embates entre os partidos e as milícias armadas nacionais e estrangeiras. 
No período que antecedeu a guerra civil de 1975, várias foram as iniciativas para reformar a constituição libanesa e mudar o seu sistema sectário. Existiam muitas visões distintas sobre qual seria a melhor fórmula para manter a governabilidade. Alguns partidos tentavam manter o status quo, outros defendiam o fim do sistema confessional ou ao menos a mudança em sua proporcionalidade. Porém, as propostas não prosperaram.

A maior parte dos acadêmicos que pesquisam a guerra civil libanesa indicam que a ação cada vez mais ativa da OLP no Líbano, e o início dos embates armados entre as façóes palestinas e os partidos cristãos, elevaram drasticamente a tensão no já frágil ambiente político libanês. Pode-se dizer que o massacre de Ayn al-Rumana foi o primeiro ato para o início da Guerra Civil Libanesa.

A eclosão da guerra foi marcada por seu primeiro massacre, conhecido como o incidente de Ayn al-Rumana, em 13 de abril de 1975, onde 27 palestinos foram mortos por militantes do Kataeb (Picard 2002: 105). Embora o ataque tenha sido claramente cometido pelo Kataeb, os líderes cristãos acusaram os palestinos e seu líder Arafat de provocar um confronto em um ambiente de tensão elevada (Hanf 1993: 204). Ayn al-Rumana foi seguida por outros massacres na chamada guerra de dois anos, de abril de 1975 a novembro de 1976 (HAUGBØLLE, 2011, tradução nossa). ${ }^{8}$

$\mathrm{O}$ início da guerra gerou a criação de duas grandes frentes. O Movimento Nacional Libanês (MNL), de inspiração Pan-Arabista e

8 The outbreak of the war was marked by its first massacre, known as the Ayn al-Rumana incident on 13 April 1975, where 27 Palestinians were killed by Kata'ib militants (Picard 2002: 105). Although the assault was clearly committed by Kata'ib, Christian leaders accused the Palestinians and their leader Arafat for provoking a confrontation in an environment of heightened tension (Hanf 1993: 204). Ayn al-Rumana was followed by other massacres in the so-called two-years war from April 1975 to November 1976. liderado pelo druso Kamal Jumblatt (Partido Socialista Progressista). O MNL era formado por partidos muçulmanos de esquerda, partidos comunistas, Pan-Arabistas e pró-soviéticos, que apoiavam a aproximação do Líbano com os regimes sírio, iraquiano e à causa Palestina.

Por sua vez, a Frente Libanesa (Lebanese Front) era liderada pelo ex-presidente Camille Chamoun (Partido Nacional Liberal), e apoiado por Pierre Gemayel (Partido Kataeb /Falanges cristâs), o ex-presidente Suleiman Franjieh (Movimento Marada), dentre outros. A Frente Libanesa era um movimento majoritariamente cristáo conservador, que buscava manter o status quo do quadro político libanês, bem como o alinhamento com o ocidente, a aproximação com Israel e a expulsão de Yasser Arafat e das forças palestinas do Líbano (HAUGBØLLE, 2011).

De acordo com Traboulsi (2012), a guerra Civil de 1975 pode ser dividida em três fases principais: de 1975 a 1976; de 1977 a 1982 e de 1983 a 1990. A primeira fase revela o maior peso dos fatores internos e do impacto da chegada da direção da OLP ao Líbano após o Setembro Negro. As disputas entre Palestinos e as Falanges cristâs criaram um ambiente de polarização que escalou para a formação das duas principais frentes da guerra. Vários massacres ocorreram nesta fase, como os de Ayn al-Rumana (contra Palestinos) e o de Damour (contra cristãos). Outro aspecto importante desse momento é a tentativa de se encontrar uma solução para o impasse libanês, a partir das forças políticas internas, porém, o assassinato de Kamal Jumblatt, a principal figura política de oposiçáo ao governo, em 1977, transformou o cenário da guerra.

Já o período de 1977 a 1982 foi muito influenciado pelo quadro geral do processo de paz árabe-israelense, entre Israel e Egito, bem 
como o fim da aliança entre o recém-eleito presidente Libanês Iliyas Sarkis com o governo Sírio e a Frente Libanesa. É notável o grau de oscilação da posição síria no Líbano, e como o pragmatismo político do presidente Hafez al Assad impactará a cada momento nos desdobramentos da guerra. Com o fim da Aliança Tripartite (Sarkis, Governo Sírio e Frente Libanesa), o jovem Bashir Gemayel (Partido Kataeb), filho de Pierre Gemayel, avança no quadro da liderança política entre os cristáos (TRABOULSI, 2012).

A disputa intrasectária foi outro fator marcante na Guerra Civil Libanesa. Essas disputas, muito comum entre grupos cristãos, ocorriam em razão de visões políticas distintas (favoráveis à presença síria ou não) e levou a uma série de assassinatos políticos, principalmente no período em tela, como o do filho do ex-presidente Suleiman Franjieh, Tony Frangieh, que também vitimou sua esposa e uma filha pequena do casal, além de mais de 40 pessoas em junho de $1978^{9}$. As disputas intrasectárias também ocorriam entre os demais grupos religiosos.

Ao final destas disputas, e com o fortalecimento do Partido Kataeb, Estados Unidos e Israel apoiaram fortemente Bashir Gemayel para a presidência do Líbano. A esperança de Israel em fechar um acordo de paz com o Líbano, a partir da aliança com o partido Falangista teria uma dupla função: por um lado afastar a presença Palestina e Síria do norte de Israel, e por outro, apoiar o governo libanês em seus embates contra a OLP, a oposição muçulmana e a presença síria. Em agosto de 1982 Bashir Gemayel é eleito presidente do Líbano, mas alguns dias antes de tomar posse, um atentado a bomba mata o presidente, iniciando a última fase da guerra.

9 Este caso ficou conhecido como o Massacre de Ehden.
O período de 1983 a 1990 representou praticamente o colapso do Estado libanês. A invasão israelense de 1982, e a criação de uma zona de segurança ao sul do país ${ }^{10}$, bem como a fragmentação do território libanês em várias regiôes independentes (cristãos ao norte, drusos no Shouf, Muçulmanos no Bekká e no sul, e Israel ao sul), tornou difícil qualquer iniciativa política para a unificação do Estado. Este processo de balcanização do país, juntamente com a presença Síria e o momento final da Guerra Fria, adicionou um elemento ainda mais mortífero. Os massacres dos campos de refugiados de Sabra e Chatilla, a destruição quase completa da infraestrutura do país e a divisão intrasectária permanente, levou à exaustão das partes envolvidas. A Guerra se encerra com a intervenção militar síria contra o governo de Michel Aoun, que forçou a implementação do Acordo de Ta'if.

A guerra civil libanesa de 1975 revelou os limites do sistema político libanês, e da exposição do país às disputas internacionais. Durante a guerra o exército israelense promoveu duas grandes invasóes, em 1978 e em 1982. A presença do exército sírio e de seu serviço de inteligência em território libanês aumentou fortemente sua influência, e o Líbano se tornou

10 A presença de Israel no sul do Líbano ocorreu em dois momentos principais, em 1978 e 1982. Após o assassinato de Bashir Gemayel, em 1982, Israel ocupou uma zona que adentrava o território libanês a partir da fronteira sul, designando esta área como uma zona de segurança. Durante esse período, essa região foi ocupada pelas Forças de Defesa de Israel, e nas áreas próximo ao rio Litani, por uma força miliciana cristã intitulada Exército do Sul do Líbano (ESL), fundada pelo ex-Major libanês Saad Haddad. Esta força paramilitar contava com apoio logístico e material de Israel, e atuava contras as forças sírias, palestinas, do Hizballah e do próprio Exército Libanês. Em maio de 2000 Israel se retira do território do Sul do Líbano (com exceção das Fazendas de Shebba) e os integrantes do ESL recebem refúgio em Israel. 
um território de disputa para sírios, palestinos, israelenses, potências mundiais e milícias confessionais libanesas.

Ao final da guerra o Líbano se encontrava em ruínas e em busca de um processo de reconciliação. A fórmula que dá fim ao conflito foi uma readequação do Pacto Nacional, conhecido como Carta de Reconciliação Nacional, assinada no dia 22 de outubro de 1989, na cidade Saudita de Táif. Este acordo ficou conhecido como o Acordo de Ta'if. Com a Assembleia libanesa reunida em Ta'if, formada por 31 parlamentares cristãos, e 31 parlamentares muçulmanos, concordaram em readequar o número e distribuição das cadeiras do parlamento Libanês, bem como as atribuiçôes do Chefe de Estado e do Chefe de Governo. O sistema em geral continuava o mesmo, mas o poder dos muçulmanos se tornava maior do que antes (ROGAN, 2009).

$\mathrm{Na}$ prática, o acordo alterou as cadeiras do parlamento de 99 para 108, sendo 54 para cristãos e 54 para muçulmanos, mudando a proporção política anterior de 6 cristãos para 5 muçulmanos para uma proporção igualitária. Além disto, reduziu os poderes do Presidente Maronita e fortaleceu os papeis do Primeiro Ministro Sunita e do Presidente do Parlamento Xiita. O acordo também previu o desarmamento de todas as milícias do Líbano, com exceção do Hizballah, que combatia Israel no sul do país. O Hizballah seria desarmado assim que o território fosse liberado. A anistia geral foi decretada, e os milicianos foram autorizados a ingressaram nas forças armadas libanesas (ROGAN, 2009).

Ao mesmo tempo que o Acordo de Ta'if revitalizou o Pacto Nacional a partir da readequação do poder político, em razão da nova realidade demográfica libanesa, também gerou um outro efeito, a "legitimação" e fortalecimento da influência Síria no Líbano. Esta condição permitirá uma constante atuação política síria nos assuntos internos e externos libaneses, e perdurará até 2005, ano do assassinato do ex-Primeiro Ministro Rafik el Hariri.

\section{A Segunda República e os Desafios Contemporâneos}

De 1990 a 2020, a Segunda República Libanesa enfrentará enormes desafios. Os primeiros dez anos foram marcados pela intensa reconstrução do país, sob o governo e liderança do Primeiro Ministro Rafik el Hariri. A revitalização de Beirute e das grandes cidades, e o sentimento de que a "Fênix libanesa" se reergueria novamente das cinzas estimulou o otimismo na população em geral. Ao mesmo tempo, várias milícias foram transformadas em partidos políticos, e a polarização de tais partidos girava em torno de uma perspectiva pró-ocidente (Estados Unidos e Europa) ou pró-Árabe (Síria, Iraque, etc.).

A saída das tropas israelenses do sul do Líbano em maio de 2000 representou uma nova transformação para o cenário político libanês, em função do fortalecimento do grupo político-militar Hizballah, que ocupou um importante espaço na política doméstica e regional. Com a ascensão do Hizballah o apoio sírio e iraniano a este grupo se transformou em uma política de intensa intervenção destes atores nos assuntos domésticos do Líbano, aprofundando a crise política no país e colocando em choque cristãos, sunitas, xiitas, drusos e demais minorias. As divisôes também eram sentidas dentro dos próprios grupos confessionais, gerando ainda mais dificuldade para a governabilidade do país. 
O Primeiro Ministro Rafik el Hariri foi uma forte liderança contra a presença síria no Líbano, e recebia amplo apoio da Arábia Saudita. $\mathrm{O}$ ápice desta disputa foi o ataque com um caminhão bomba contra sua comitiva em 14 de fevereiro de 2005 em Beirute, que vitimou a ele e mais 21 pessoas. $\mathrm{O}$ assassinato do Primeiro Ministro foi apontado pela opinião pública libanesa como de responsabilidade do governo sírio e do Hizballah, e gerou uma grande comoçáo nacional.

A mobilização popular criou um movimento conhecido como Revoluçáo dos Cedros, e no dia 14 de março de 2005, mais de 1,5 milhôes de libaneses ocuparam a Praça dos Mártires em Beirute para exigir a retirada do exército sírio do Líbano, a manutenção de sua soberania, bem como a destituição de todo governo libanês, considerado pró-Síria. A pressão nacional e internacional foi intensa, o que levou as $\mathrm{Na}$ çóes Unidas a aprovarem a Resolução 1595 do Conselho de Segurança em 07 de abril de 2005, que determinou o respeito à independência e soberania do Líbano, além de uma investigação sobre o assassinato de Hariri, sob os auspícios do Tribunal Especial para o Líbano. Em 26 de abril de 2005 o Exército Sírio se retirou do país.

A partir deste momento a política libanesa se polarizou em duas grandes coalizões. A primeira conhecida como 14 de Março $^{11}$, liderada pelo filho de Rafik el Hariri, Saad Hariri, e com presença maciça de sunitas (partido Futuro), parte dos cristãos (partido Kataeb, Forças Libanesas e Movimento Patriótico Livre) e drusos (Partido Progressista Socialista). Este grupo era apoiado pela Arábia Saudita, Estados Unidos e países europeus.

11 O nome 14 de Março originou-se em razão do grande protesto ocorrido em Beirute no dia 14 de março de 2005, contra o assassinato do Primeiro Ministro Rafik el Hariri.
A outra coalizão foi a 8 de Março $^{12}$, formada pelos xiitas (Partidos Hizballah e Amal), parte dos cristãos (Movimento Marada, Partido Social Nacionalista Sírio, dentre outros) e por uma outra parte dos drusos (Partido Democrático Libanês). A Síria, Irã e Rússia eram os principais apoiadores desta aliança. Esta realidade influencia notadamente as relaçôes políticas até a atualidade. Nos anos subsequentes, vários partidos mudaram de coalizão, como o caso do partido de Michel Aoun, o Movimento Patriótico Livre, que se alinhou ao grupo 8 de Março, e o partido Progressista Socialista, de Walid Jumblatt, que se torna independente, mesmo mantendo o apoio o partido Futuro, de Saad Hariri.

No ano seguinte, após uma incursão do Hizballah às Fazendas de Shebba ${ }^{13}$, o que acabou com a morte de vários soldados israelenses na ação, gerou o conflito conhecido como a Guerra do Líbano, em 2006. A resposta israelense foi uma ação militar devastadora contra o território libanês, o que agravou seu quadro político e humanitário. Por outro lado, o custo para o exército israelense também foi alto, em virtude das perdas impostas pelo Hizballah.

12 O nome 8 de Março originou-se em razão de um comício organizado pelo Hizballah e partidos aliados no dia 8 de março de 2005, para agradecer a participação da Síria no processo que levou ao fim da Guerra Civil de 1975 e pela estabilização do Líbano.

13 Território libanês ocupado por Israel na Guerra de 1967, localizado na fronteira entre Líbano, Israel e Síria (Colinas de Golã). A controvérsia sobre a ocupação das Fazendas de Shebba remonta o mandato francês, que indicava que a área pertencia ao Líbano, porém, na década de 1950 foi ocupada pelos sírios, e posteriormente por Israel, na Guerra dos Seis Dias, em 1967. O território compreende uma área pequena de aproximadamente $38 \mathrm{Km} 2$, nas proximidades do Monte Hermon. O Governo Libanês reafirma o direito sobre o território, e o grupo Hizballah não aceita o desarmamento de sua milícia armada por dizer que Israel ainda não se retirou completamente do território libanês. 
O episódio revelou a dificuldade do controle do exército libanês de todo território nacional, e o papel do Hizballah como uma força paralela que acabava por absorver a capacidade de ação do Exército Libanês.

A polarização política no Líbano se tornou tão intensa que no ano de 2007, após o fim do mandato presidencial, o cargo ficou em vacância por 8 meses, pela incapacidade dos grupos políticos encontrarem uma liderança que pudesse acomodar os interesses dos dois campos majoritários. Em 2014, mais uma vez, o país ficou 30 meses sem presidente, revelando a persistência da crise política.

$\mathrm{Na}$ esteira da Primavera Árabe, o Líbano foi aparentemente pouco afetado pela onda de protestos que se alastrou pelo Oriente Médio. Porém, nos anos subsequentes, a entrada de mais de um milhão de refugiados sírios no Líbano e a ativa participação do Hizballah no conflito, gerou impactos na economia e na segurança do país. A crise econômica e a carência de empregos se aprofundou, e a reiterada incapacidade do Estado libanês em prover a populaçáo com serviços essenciais alimentou ainda mais a insatisfação da opinião pública.

Em 2015 uma crise na coleta de lixo indicou a incapacidade do Estado libanês em prover serviços públicos básicos, como a limpeza urbana e depósito de resíduos, o que gerou o início de protestos populares. O acúmulo do lixo nas cidades, e o impasse do governo em resolver onde poderiam alocar os resíduos, mostrava que o embate político estava presente em todos os níveis do governo.

Porém, os acontecimentos que abalaram o Líbano a partir de outubro de 2019 sinalizam que mais um momento de ruptura poderá ocorrer no país. Após o governo anunciar o aumento de imposto sobre a gasolina, tabaco e chamadas via in- ternet com aplicativos, a população iniciou uma forte mobilização nacional. Críticas ao modelo político confessional; à profunda crise econômica e desvalorização da Lira Libanesa, que chegou a perder mais de $80 \%$ de seu valor; à incapacidade do Estado em prover serviços públicos básicos como energia elétrica, água tratada e coleta de lixo; percepção de corrupção generalizada na classe política e de leis que protegiam políticos e a elite, levaram a uma mobilização geral no país.

Os jovens fecharam estradas, ruas, promoveram greves gerais e protestos em massa foram observados em todo o país. No início as manifestações eram majoritariamente pacíficas, e não sectárias. Os manifestantes exigiam a saída de todo o governo, a quem responsabilizavam pela condição de empobrecimento contínuo da populaçáo e pelo aumento da fome. Colocaram como condição para acabar com a mobilização a criação de um governo de tecnocratas, sem a presença dos políticos que há décadas ocupavam cargos públicos. Além disto pressionavam para que a Constituição libanesa fosse respeitada, no que diz respeito ao fim do sistema confessional do país, solicitando seu fim, já que a própria constituição, em seu preâmbulo indica que : "Eliminar o sectarismo político é um objetivo básico nacional, a ser alcançado de acordo com um plano de transiçáo" (LÍBANO, 2004, tradução nossa) ${ }^{14}$.

Com a pandemia da COVID-19 as manifestações arrefeceram, porém, com a reabertura relativa no Líbano no início de junho de 2020, os protestos voltaram a ocorrer. No dia 6 de junho de 2020 embates entre grupos de manifestantes favoráveis ao ex-Primeiro Ministro Saad Hariri, com manifestantes favoráveis ao Hizballah in-

14 Eliminating political sectarianism is a basic national objective, to be achieved according to a transitional plan. 
dicaram o crescimento de feiçóes sectárias nos protestos, trazendo preocupação para a sociedade libanesa e para a região. $\mathrm{O}$ aprofundamento da violência sectária pode reviver experiências pretéritas dolorosas que marcaram a vida dos libaneses nas décadas de 1970 e 1980.

No dia 04 de agosto de 2020 duas explosôes ocorreram no Porto de Beirute. A segunda explosão, às 18:07 (horário local), de dimensão cataclísmica, destrói o porto da cidade. $\mathrm{O}$ condicionamento inadequado de 2.750 toneladas de Nitrato de Amônia ${ }^{15}$ armazenado no depósito $\mathrm{n}^{\circ} 12$ do porto de Beirute, levou à maior explosão não nuclear da história do mundo contemporâneo. A onda de choque da explosão foi tão intensa que devastou boa parte da capital libanesa, e seus efeitos foram sentidos a centenas de quilômetros do epicentro da explosão.

A explosão foi equivalente a um terremoto de 3 pontos na escala Richter, e para alguns pesquisadores, foi proporcional a $20 \%$ da explosão nuclear ocorrida na cidade Japonesa de Hiroshima, em 1945 (SIZE..., 2020). Essa tragédia gerou um número de aproximadamente 190 mortos, mais de 6.500 feridos, 300.000 desabrigados e mais de uma dezena de desaparecidos. As perdas materiais são projetadas em 15 bilhões de dólares (Agência Reuters, 2020).

Em um primeiro momento levantou-se a possibilidade de um ataque aéreo ou um atentado terrorista, ambas possibilidades foram descartadas pelas autoridades libanesas, que indicaram que a explosão teria sido resultado de um acidente. De acordo com os relatos do governo libanês, a carga de Nitrato de Amônia havia sido apreendida no porto de Beirute e guardada no depósito $\mathrm{n}^{\circ} 12$ desde junho de 2014 .

15 Substância utilizada como fertilizante, mas altamente explosiva quando submetida à alta temperatura. Material também utilizado para fabricação de explosivos.
Esta tragédia deixou mais evidente a incapacidade do Estado Libanês em lidar com seus problemas mais triviais. $\mathrm{O}$ ato negligente das autoridades locais, de permitir a guarda de material notadamente conhecido por provocar tragédias pelo mundo, em uma área densamente povoada, e não agir no sentido de fazer valer as inspeçôes e açóes para correção do problema, revela a inoperância do Estado.

O país já combalido pela crise econômica, que elevou o número de desempregados e desnutridos, favoreceu o início de uma nova onda de emigraçáo de libaneses pelo mundo. O quadro da pandemia da Covid-19, que intensificou seu contágio após a explosão do dia 04 de agosto tornou a situação ainda mais delicada para os grupos de risco no Líbano. A presença de mais de um milhão de refugiados sírios e palestinos no país ${ }^{16}$, que carecem de apoio internacional para auxiliar nos esforços de acolhimento e manutenção desta população impactam sobre a já delicada economia libanesa.

A crise política que se arrasta por anos, que mistura o esgotamento do sistema sectário libanês e as disputas locais e regionais envolvendo principalmente Irã, Arábia Saudita e Israel, dificulta a constituição de governos com representação popular e estáveis. Estes fatores em conjunto tornam a solução dos problemas do Líbano ainda mais difíceis.

Os protestos voltaram com força logo após a tragédia do dia 4 de agosto, e a praça dos Mártires em Beirute transformou-se mais uma vez em um campo de batalha entre os manifestantes e o atual governo. A renúncia de ministros e parlamentares sinalizou para o tamanho da pressão que os políticos começaram a sofrer.

16 O Líbano é o país com o maior número per capita de refugiados no mundo. 
Figura 3 - Explosão no Porto de Beirute de 04 de agosto de 2020

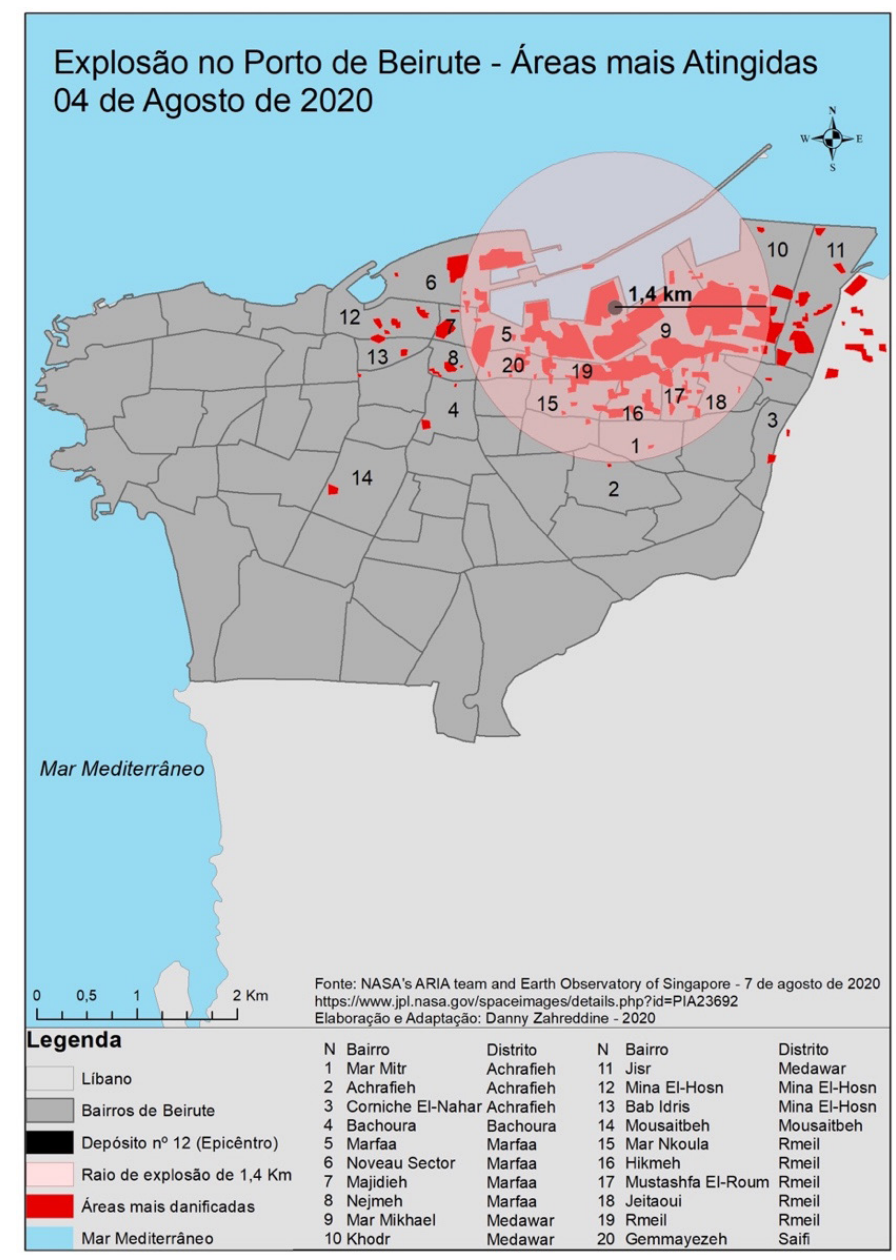

Fonte: Elaborado e adaptado pelo autor com dados de (NASA, 2020).

O Primeiro Ministro Libanês Hassan Diab solicitou a prisão domiciliar de algumas autoridades envolvidas na gestão do porto de Beirute desde 2014, e prometeu solicitar a antecipação de novas eleiçóes. Mesmo assim, não foi capaz de lidar com a crise política, e no dia 10 de agosto de 2020, apresentou a renúncia de seu governo.

Porém, somente a renúncia do governo não será suficiente para lidar com os grandes desafios do porvir. Além da dor pelas mortes, os feridos deverão ser tratados, os desabrigados que perderam suas casas e propriedades deverão ser acomodados provisoriamente e ressarcidos. Um novo governo de transição deverá liderar a reconstrução da capital, a retomada da econo- mia e reformas eleitorais e políticas.

A elite política que está no poder no Líbano é a mesma que levou o país à guerra civil em 1975, e a principal reivindicação dos manifestantes é que ocorra uma mudança geracional e de perfil no comando da nação. Para que tais mudanças ocorram, o primeiro passo será conseguir mudar a atual legislação eleitoral, pois em seu atual formato dificulta a participação de partidos independentes e da sociedade civil, privilegiando o sistema sectário em vigor e seus respectivos currais eleitorais.

Para tornar o ambiente político ainda mais tenso, no dia 18 de agosto de 2020, o Tribunal Especial para o Líbano (STL), que julgava a mais de 15 anos o assassinato do ex-Primeiro 
Ministro Rafik el Hariri, divulgou seu veredito final. O tribunal já havia indiciado três membros do grupo Hizballah como suspeitos pelo atentado, mas em sua sentença final aponta como responsável somente Salim Ayyash, inocentando os demais. Ao mesmo tempo apontou que náo existiram provas materiais que pudessem indicar a participação da Síria e do Hizballah no assassinato. Os desdobramentos políticos desta sentença ainda serão sentidos nos próximos anos.

É neste quadro instável que a jovem República Libanesa busca encontrar seu caminho. Os ecos do passado ainda assombram fortemente a realidade atual. As divisóes internas, e as intervenções externas têm se manifestado repetidamente na história libanesa, e as decisôes do passado continuam a apresentar desafios que exigirão dos libaneses fórmulas capazes de suplantar o sectarismo. $\mathrm{O}$ esgotamento do Pacto Nacional talvez esteja levando o país a uma outra fase, e a necessidade dos libaneses repensarem suas instituiçóes e formas pacíficas de governança uma tarefa urgente para as novas geraçôes que habitam a Terra dos Cedros.

\section{Referência}

CALFAT, Natalia Nahas. The Frailties of Lebanese Democracy: Outcomes and Limits of the Confessional Framework. Contexto Internacional, Rio de Janeiro, v. 40, n. 2, p. 269292 mai./ago. 2018.

GARNIER F.A. Atlas, Asie Mineure, Turquie D’Asie Syrie, Liban, Region Du Caucase, Paris, 1861. Disponível em: https://www. raremaps.com/gallery/detail/24247/asie-mineure-turquie-dasie-syrie-liban-region-du-caucase-garnier. Acesso em: 15 jul. 2020.
HARRIS, William. Lebanon: A History 600-2011. Oxford: Oxford University Press, 2012.

HAUGBØLLE, Sune. The historiography and the memory of the Lebanese civil war. 2011. Disponível em: https://www. sciencespo.fr/mass-violence-war-massacre-resistance/fr/document/historiography-and-memory-lebanese-civil-war.html. Acesso em: 20 ago. 2020.

KHALAF, Samir. Civil and uncivil violence in Lebanon: a history of the internationalization of communal conflict. New York: Columbia University Press, 2002.

KAMRAVA, Mehran. The Modern Middle East: A Political History since the First World War. Los Angeles: University of California Press, 2005.

KAUfFMAN, Asher. Reviving Phoenicia: The Search for Identity in Lebanon. London: I.B.Tauris, 2004.

LÍBANO. [Constituição (1926)]. Constituicão da República do Líbano. Traduzido por Fouad Fahmy Shafik e Abed Awad. Oxford: Oxford University Press, 2004.

LIJPHART, Arendt. Thinking about Democracy Power sharing and majority rule in theory and practice. New York: Routledge, 2008.

MAKTABI, Rania. Lebanese Census of 1932 Revisited. Who are the Lebanese? British Journal of Middle Eastern Studies. v. 26, n. 2, p. 219-241, 1999.

NASA. NASA's ARIA team and Earth Observatory of Singapore. Disponível em: https://www.jpl.nasa.gov/spaceimages/ details.php?id=PIA23692. Acesso em: 7 ago. 2020.

REUTERS, 2020. Disponível em: https://www.reuters.com/ article/us-lebanon-crisis-blast-casualties-idUSKBN25Q08H. Acesso em: 30 ago. 2020.

ROGAN, Eugene L. The Arabs: a history. New York: Basic Books, 2009.

SALIBI, Kamal. A House of Many Mansions: The History of Lebanon Reconsidered. London: 1.B.TAURIS \& CO LTD, 1988.

SIZE of Beirut's blast 'astonishing'. The Daily Star Lebanon, Beirute, 05 ago. 2020. Disponível em: http://www.dailystar. com.lb/News/Lebanon-News/2020/Aug-05/509904-size-of-beiruts-blast-astonishing.ashx. Acesso em: 10 ago. 2020.

TRABOULSI, Fawwaz. A History of Modern Lebanon. London: Pluto Press, 2012.

ZISSER, Eyal. Lebanon: The Challenge of Independence. London: I.B.Tauris, 2000. 